\title{
Analisis Implementasi Tata Naskah Dinas dalam Pembuatan Surat Dinas di Lingkungan Universitas Gadjah Mada (UGM)
}

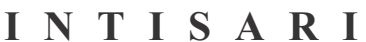

Naskah dinas merupakan salah satu sarana komunikasi tertulis yang digunakan dalam kegiatan administrasi perguruan tinggi. Agar tercipta keseragaman naskah dinas, UGM menyusun kebijakan tata naskah dinas. Penelitian ini bertujuan untuk menilai kesesuaian antara tata naskah dinas dalam pembuatan surat dinas yang diimplementasikan di lingkungan UGM dengan Peraturan Rektor UGM Nomor 13 Tahun 2018 tentang Tata Naskah Dinas di Lingkungan UGM dan faktor-faktor yang mempengaruhinya. Adapun unit kerja yang menjadi narasumber dalam penelitian ini adalah fakultas yang telah mengikuti diklat tata naskah dinas. Fakultas yang terbagi dalam 4 klaster dipilih berdasarkan hasil penelitian awal yaitu fakultas yang sudah mengimplementasikan dan yang belum mengimplementasikan peraturan tata tata naskah dinas. Penelitian ini menggunakan metode deskriptif dan cara memperoleh data adalah dengan wawancara, observasi, dan dokumentasi. Pengujian validitas data dalam penelitian ini menggunakan triangulasi. Hasil yang diperoleh menunjukkan bahwa implementasi tata naskah naskah dinas yang meliputi kelengkapan bagian surat, format, penomoran, dan kewenangan penanda tangan surat dilakukan belum sesuai dengan peraturan rektor. Faktor-faktor yang mempengaruhi ketidaksesuaian implementasi tata naskah dinas tersebut adalah standarisasi kode, sosialisasi, kompetensi pegawai, penggunaan sistem informasi, komitmen pimpinan, dan kebiasaan.

\section{$\begin{array}{llllllll}A & B & S & T & R & A & C & T\end{array}$}

Official correspondence is one of the means of written communication used in the activities of the college administration. This research was carried out because of the irregularity of the official
PENULIS

Fitria Agustina

Wahyudi Kumorotomo Ida Fajar Priyanto

Program Studi Magister Manajemen

Pendidikan Tinggi UGM fitz_08@ugm.ac.id

KATA KUNCI

implementasi kebijakan, surat dinas, tata naskah dinas

KEY WORDS

correspondence management, official correspondence, policy implementation 
correspondence format used in UGM. This study aims to assess the suitability of the correspondence management in making official letters implemented at UGM with the Peraturan Rektor UGMNomor 13 Tahun 2018 tentang Tata Naskah Dinas di Lingkungan UGM and the factors that influence them. The work units that are the speakers in this study are faculties that have participated in correspondence management training. The faculty which is divided into 4 clusters is selected based on the results of the initial research, namely the faculty that has implemented and has not implemented the rules for correspondence management This research uses descriptive method and the way to obtain data is by interview, observation, and documentation. Testing the validity of the data in this study uses triangulation. The results obtained state that the implementation of correspondence management that include the completeness of the letter section, format, numbering, and the authority of the signatory to the letter are carried out not in accordance with the rector's regulation. The factors that influence the implementation of the correspondence management are code standardization, socialization, employee competency, use of information systems, leadership commitment, and habit.

\section{PENGANTAR}

\section{Latar Belakang Masalah}

Surat merupakan sarana penyampaian informasi dalam setiap organisasi. Meskipun terjadi percepatan perubahan teknologi informasi, keberadaan surat terus dipertahankan. Tidak hanya berbentuk tekstual, dengan perkembangan teknologi saat ini memungkinkan penggunaan surat elektronik karena lebih mudah dan lebih cepat penyampaiannya. Surat sebagai alat komunikasi perlu dikelola dengan baik dan tepat dalam menunjang efisiensi dan efektivitas organisasi.

Kemajuan teknologi yang menawarkan kemudahan dalam pembuatan dan penyampaian surat juga rentan terhadap penyimpangan. Adanya teknologi yang canggih orang bisa melakukan kejahatan dengan menggunakan berbagai cara, salah satunya menggunakan modus surat. Oleh karena itu, untuk menjaga keamanan dan keautentikan surat perlu dibuat pedoman baku yang berlaku pada surat tekstual dan surat elektronik. Pedoman tersebut berupa kebijakan tata naskah dinas.

Pada pertengahan tahun 2018, ramai dibicarakan di kalangan arsiparis, pengelola arsip, dan pejabat kearsipan mengenai penipuan yang bermodus surat undangan penyelenggaraan pendidikan dan pelatihan (diklat) kearsipan. Surat 
u n d a n g n n o m o r B DL.00.02/91/VII/2018 tersebut tentang penyelenggaraan diklat yang mengatasnamakan Pusat Pendidikan dan Pelatihan (Pusdiklat) Arsip Nasional Republik Indonesia (ANRI). Sudah ada beberapa instansi yang menjadi korban penipuan tersebut karena telah mentransfer sejumlah uang sesuai dengan biaya keikutsertaan menjadi peserta diklat. Kejadian tersebut terjadi berulang kali dan ANRI telah memberikan klarifikasi melalui surat nomor BHM.00/1656/2019. ANRI menyatakan bahwa surat undangan yang beredar tersebut palsu dan dapat dibuktikan menggunakan Pedoman Tata Naskah Dinas yang berlaku di lingkungan ANRI.

Kejadian serupa terjadi pada Oktober 2018 berupa penipuan dan pemerasan menggunakan surat perintah Deputi Pencegahan Badan Narkotika Nasional (BNN). Dari berita yang dimuat dalam www.tribunnews.com dinyatakan bahwa surat yang beredar tersebut adalah palsu. Informasi tersebut sesuai dengan yang disampaikan oleh Kepala Bagian Humas BNN, Sulistriandri, yang menyatakan bahwa telah ditemukan kejanggalan dan kesalahan dalam surat perintah tersebut. Berdasarkan tata naskah yang berlaku di lingkungan BNN, nomor yang tertera dalam surat tersebut bukan sistem penomoran yang ada di Deputi Bidang Pemberantasan BNN. Selain itu, tidak dicantumkan tanggal penandatanganan surat dan yang membuktikan bahwa surat tersebut palsu adalah terkait dengan kewenangan penandatangan surat.

Dalam manajemen kearsipan, posisi naskah dinas berada dalam tahap penciptaan. Kegiatan yang termasuk dalam penciptaan arsip adalah pembuatan dan penerimaan arsip, di mana tata naskah dinas berperan penting dalam kegiatan penciptaan tersebut. Berdasarkan contoh dua kasus tersebut menunjukkan bahwa peranan tata naskah dinas dalam suatu organisasi, terutama organisasi pemerintah sangat penting. Tidak hanya sebagai alat untuk membuktikan keautentikan surat apabila terjadi kejahatan yang menggunakan modus surat seperti dua kasus tersebut, tetapi juga nantinya surat akan menjadi arsip (dinamis maupun statis) yang merupakan bukti sejarah dari dinamika perjalanan suatu organisasi. Melalui arsip surat dapat diketahui perkembangan dan sejarah perjalanan organisasi.

Autentisitas dalam penciptaan arsip harus dilakukan berdasarkan tata naskah dinas yang digunakan. Hal ini sejalan dengan Azmi (2016:17) yang menyampaikan bahwa penguatan tata naskah dinas dalam pengelolaan arsip dinamis terkait dengan jaminan terhadap tingkat autentisitas dan reliabilitas arsip yang tercipta (yang dibuat dan diterima). Autentisitas adalah kualitas suatu arsip yang sebagaimana adanya dan tidak mengalami perubahan. Hal ini dilakukan karena pada saat arsip nantinya menjadi statis, arsip 
yang diserahkan oleh pencipta arsip kepada lembaga kearsipan harus merupakan arsip yang utuh, autentik, terpercaya, dan dapat digunakan. Selain itu, arsip yang autentik dan utuh dapat menjadi bukti terpercaya, misalnya dalam pengadilan.

Hal senada disampaikan oleh Hendrawan dan Ulum (2017:21) menyatakan bahwa untuk memenuhi autentisitas dan reliabilitas arsip serta pengelompokan arsip sebagai satu keutuhan informasi maka dalam pembuatan arsip dilaksanakan berdasarkan instrumen baku kearsipan yaitu tata naskah dinas, klasifikasi arsip, jadwal retensi arsip serta klasifikasi keamanan dan akses arsip.

Pada tahapan pengelolaan arsip dinamis, yang dimulai dari tahap penciptaan, penggunaan dan pemeliharaan, hingga tahap penyusutan arsip belum dilakukan dengan maksimal dalam mendukung tata kelola pemerintahan yang baik. Azmi (2016:17) menyatakan bahwa salah satu faktor penyebab belum baiknya pengelolaan arsip dinamis tersebut adalah, karena tidak adanya keinginan kuat pencipta arsip untuk melaksanakan pengelolaan arsip dinamis secara benar melalui penerapan empat instrumen pokok pengelolaan arsip dinamis, yaitu tata naskah dinas, klasifikasi arsip, jadwal retensi arsip, serta sistem klasifikasi keamanan dan akses arsip dalam pengelolaan arsip dinamis. Keempat instrumen pokok ini berfungsi sebagai faktor pengontrol praktik setiap tahapan dalam pengelolaan arsip dinamis mulai tahap penciptaan, penggunaan dan pemeliharaan arsip sampai dengan tahap penyusutan arsip.

UGM sebagai salah satu perguruan tinggi di Indonesia melaksanakan tri darma perguruan tinggi, yaitu pendidikan, penelitian, dan pengabdian kepada masyarakat sebagai salah satu peran strategis dalam membangun peradaban bangsa. Dalam melaksanakan fungsi tersebut, UGM menghasilkan arsip yang mempunyai bermanfaat dalam kehidupan bermasyarakat. Arsip yang diciptakan perguruan tinggi merupakan memori kolektif perguruan tinggi dan bagian dari memori kolektifbangsa.

Arsip memiliki peranan yang penting dalam menunjang kegiatan tri darma perguruan tinggi. Utomo (2012: 248) menjelaskan bahwa ketertiban dan kepatuhan merupakan syarat utama yang harus dipenuhi, tidak saja oleh organ kearsipan tetapi juga organ-organ bagianbagian di universitas, apabila ingin memanfaatkan, mendayagunakan arsip sebagai penunjang terwujudnya universitas penelitian. Hal ini berarti dalam proses pengelolaan arsip, dari tahap penciptaan sampai dengan penyusutan harus sesuai dengan pedoman yang digunakan.

Surat dinas merupakan salah satu bentuk arsip yang tercipta di lingkungan UGM. UGM menggunakan surat baik tekstual maupun elektronik dalam melakukan komunikasi internal dan 
eksternal. Pada manajemen kearsipan, posisi naskah dinas berada dalam tahap penciptaan arsip yang mempunyai kaitan langsung dalam perjalanan arsip menuju pelestariannya (arsip statis). Agar arsip yang tercipta tersebut bersifat utuh, autentik, terpercaya, dan dapat digunakan, perlu dijaga kualitas arsip sebagaimana adanya agar tidak mengalami perubahan. Kualitas arsip ditentukan pada saat penciptaannya.

Upaya yang dilakukan UGM untuk menjaga kualitas arsip yang tercipta adalah dengan menerbitkan peraturan Rektor tentang tata naskah dinas. Upaya tersebut sebagai bentuk respon dari Peraturan Menteri Riset, Teknologi, dan Pendidikan Tinggi Nomor 51 Tahun 2015 tentang Tata Naskah Dinas di Lingkungan Kementerian Riset, Teknologi, dan Pendidikan Tinggi (Kemenristekdikti).

Peraturan yang pertama adalah Peraturan Rektor UGM Nomor 2/P/SK/HT/2015 tentang Tata Naskah Dinas di Lingkungan UGM. Kemudian pada akhir tahun 2016 Kantor Hukum dan Organisasi UGM bersama dengan Bagian Tata Usaha dan Rumah Tangga UGM melakukan pengkajian ulang dan evaluasi pelaksanaan Peraturan Rektor UGM Nomor 2/P/SK/HT/2015 tentang Tata Naskah Dinas UGM. Berdasarkan hasil kajian dan evaluasi tersebut perlu dilakukan perancangan ulang Peraturan Rektor UGM tentang Tata Naskah Dinas.

Menurut Adhi Firmana, dalam artikel yang diambil dari hktl.ugm.ac.id/v2/uji-publik-rancanganperaturan-rektor-universitas-gagjahmada-tentang-tata-naskah-dinasuniversitas-gadjah-mada/, salah satu tahapan dalam dalam penyusunan sebuah peraturan perundang-undangan adalah uji publik. Uji publik merupakan kegiatan pembahasan secara mendalam dan penjaringan aspirasi dalam rangka penyempurnaan materi muatan yang diatur dalam sebuah peraturan. Demikian juga dengan rancangan Peraturan Rektor UGM tentang Tata Naskah Dinas perlu melalui tahapan uji publik. Hal ini dilakukan dalam rangka penyempurnaan proses pembentukan peraturan internal universitas yang lebih baik, dapat diimplementasikan, dan diterima oleh para subjek yang diatur dalam peraturan tersebut. Selanjutnya peraturan tersebut direvisi dalam Peraturan Rektor Nomor 13 Tahun 2018 tentang Tata Naskah Dinas di Lingkungan UGM.

Menurut Fatima dalam artikel yang d i a m b i $1 \quad d$ a r i https://sdm.ugm.ac.id/kegiatan/diklattata-naskah-dinas-menuju-standardisasitata-naskah-dinas-di-lingkungan-ugm/, tujuan tata naskah dinas adalah untuk keseragaman dalam penerapan, identitas institusi, tertib administrasi, dan kualitas layanan administrasi. Harapan dari adanya peraturan ini adalah semua unit kerja di lingkungan UGM dapat mengimplementasikan dalam semua kegiatan administrasi yang mendukung kinerja universitas. Hal tersebut 
disampaikan oleh panitia dalam Pendidikan dan Pelatihan Tata Naskah Dinas yang dilaksanakan pada 16-19 Oktober 2018.

Tujuan implementasi tata naskah dinas diperkuat dengan Surat Edaran Sekretaris Jenderal Kemenristekdikti Nomor 3775/A.A3/SE/2017 tentang Kewenangan Penandatangan Surat Dinas di Lingkungan Kemenristekdikti. Surat Edaran tersebut menjelaskan beberapa ketentuan yang terkait dengan penggunaan surat dinas sebagai salah satu sarana komunikasi resmi di lingkungan Kemenristekdikti. Beberapa ketentuan yang disampaikan di antaranya bahwa dalam penyelenggaraan administrasi pemerintahan serta penyeragaman tata naskah dinas agar mematuhi tata naskah sesuai dengan Permenristekdikti No. 51 Tahun 2015 tentang Tata Naskah Dinas di Lingkungan Kemenristekdikti. Selain itu, demi terselenggaranya tata kelola pemerintahan yang bersih dan efisien, pimpinan unit di lingkungan Kemenristekdikti agar waspada dan tidak melayani permintaan dari pihak-pihak yang mengatasnamakan kementerian yang bertentangan dengan peraturan yang berlaku. Hal ini sebagai bentuk antisipasi kementerian untuk melindungi dari berbagai bentuk kejahatan kaitannya dengan penggunaan naskah dinas.

Selama ini, kondisi di UGM dalam pembuatan surat dinas belum ada keseragaman. Bahkan dalam kurun 3 tahun sejak peraturan rektor tentang naskah dinas tersebut ditetapkan, masih dijumpai surat dinas yang belum sesuai dengan peraturan tata naskah dinas. Kondisi sekarang, setelah dilaksanakan sosialisasi Peraturan Rektor Nomor 13 Tahun 2018 tentang Tata Naskah Dinas di Lingkungan UGM dan diklat tata naskah dinas, belum semua unit kerja menerima dengan baik dan berupaya mengimplementasikannya. Masih dijumpai ketidakseragaman dalam pembuatan naskah dinas.

Hal senada disampaikan oleh Dra. Emmy Indjatmiati, M.Si. perihal pentingnya penyamaan persepsi dalam penyusunan tata naskah dinas di setiap unit kerja yang merupakan satu kesatuan bagian dari UGM. Selanjutnya juga disampaikan bahwa ketidakseragaman bentuk tata naskah dinas yang dikeluarkan antar unit kerja merupakan permasalahan yang masih terjadi di UGM. Banyak unit kerja yang belum mengetahui susunan tata naskah dinas yang baku, yang seharusnya digunakan seragam di setiap unit di UGM. Hal tersebut sesuai dengan Fatima dalam artikel yang diambil dari https://sdm.ugm.ac.id/kegiatan/diklattata-naskah-dinas-menuju-standardisasitata-naskah-dinas-di-lingkungan-ugm/.

Salah satu tahapan terpenting dalam suatu kebijakan adalah implementasi. Winarno (2017: 155-156) menyebutkan bahwa implementasi kebijakan adalah salah satu tahap kebijakan publik, antara pembentukan kebijakan dan konsekuensikonsekuensi kebijakan bagi masyarakat 
yang dipengaruhinya. Suatu kebijakan akan mengalami kegagalan jika kebijakan tersebut kurang diimplementasikan dengan baik oleh para pelaksana kebijakan.

Surat dinas merupakan salah satu jenis naskah dinas yang berkenaan dengan administrasi universitas. Surat dinas digunakan sebagai sarana komunikasi baik internal maupun eksternal. Oleh karena itu, penelitian ini ditujukan untuk mengkaji implementasi tata naskah dinas dalam pembuatan surat dinas yang dilakukan oleh fakultas melalui implementasi Peraturan Rektor UGM Nomor 13 Tahun 2018 tentang Naskah Dinas di Lingkungan UGM dan penyebab fakultas belum mengimplementasikannya secara serentak di unit kerja masingmasing.

\section{Rumusan Masalah}

Penelitian ini dibatasi hanya pada salah satu jenis naskah dinas yaitu surat dinas. Penelitian ini menganalisis kesesuaian antara implementasi pembuatan surat dinas dengan Peraturan Rektor UGM Nomor 13 Tahun 2018 tentang Naskah Dinas di Lingkungan UGM. Kesesuaian yang dimaksud dalam penelitian ini adalah memiliki kesamaan isi dan definisi sesuai dengan peraturan tata naskah dinas tersebut.

\section{Tujuan Penelitian}

Tujuan penelitian ini adalah untuk mengetahui implementasi tata naskah dinas dalam pembuatan surat dinas yang diimplementasikan oleh fakultas, menilai kesesuaian antara implementasi pembuatan surat dinas dengan Peraturan Rektor UGM Nomor 13 Tahun 2018 tentang Naskah Dinas di Lingkungan UGM, dan mengidentifikasi faktor-faktor yang mempengaruhi implementasi tata naskah dinas dalam pembuatan surat dinas melalui Peraturan Rektor UGM Nomor 13 Tahun 2018 tentang Tata Naskah Dinas di Lingkungan UGM.

\section{Metodologi Penelitian}

Fokus penelitian ini adalah implementasi kebijakan tata naskah dinas dalam pembuatan surat dinas di UGM dan faktor-faktor yang mempengaruhinya. Agar mendapatkan data yang rinci, jelas, dan mendalam, penelitian ini menggunakan pendekatan kualitatif dengan metode deskriptif. Metode deskriptif menjadi pilihan untuk memenuhi kebutuhan dalam menjawab permasalahan dalam penelitian ini yaitu mendapatkan gambaran secara menyeluruh dan mendalam mengenai implementasi peraturan rektor tentang tata naskah dinas dalam pembuatan surat dinas dan kendala yang dihadapi oleh UGM dalam rangka implementasinya. Penelitian deskriptif pada dasarnya merupakan langkah untuk reinterpretasi objektif tentang data dan fakta yang didapat sesuai dengan permasalahan yang sedang diteliti. Menurut Ibrahim (2015:59), penelitian deskriptif kualitatif 
dimaksudkan untuk melukiskan, menggambarkan, atau memaparkan keadaan objek yang diteliti sebagaimana adanya, sesuai dengan situasi dan kondisi ketika penelitian tersebut dilakukan.

Informan dipilih secara purposive sampling, yaitu pihak yang terlibat dalam penyusunan, sosialisasi, dan unit kerja di lingkungan UGM sebagai pengguna dari peraturan tersebut. Sebagai pengguna, fakultas yang dipilih adalah yang telah mendapatkan sosialisasi dan diklat tata naskah dinas yang dilaksanakan pada bulan Oktober 2018. Ada 9 fakultas yang dipilih berdasarkan klaster yaitu Fakultas Farmasi, Ilmu Budaya, MIPA, Kehutanan, Kedokteran Gigi, Kedokteran Hewan, Psikologi, Teknik, dan Sekolah Pascasarjana.

Metode pengumpulan data yang digunakan untuk memperoleh gambaran secara menyeluruh tentang evaluasi implementasi kebijakan tata naskah dinas dalam pembuatan surat dinas di lingkungan UGM adalah melalui wawancara, observasi atau pengamatan langsung, dan studi dokumen.

Metode analisa data yang akan dilakukan dalam penelitian ini yaitu pengumpulan data, klasifikasi data, dan interpretasi data. Pengujian validitas data dalam penelitian ini dilakukan dengan triangulasi. Moelong (2016:330) memaknai triangulasi merupakan teknik pemeriksaan keabsahan data yang memanfaatkan sesuatu yang lain diluar data itu untuk keperluan pengecekan atau sebagai pembanding terhadap data itu.

\section{Kerangka Pemikiran}

Salah satu tahapan terpenting dalam sebuah kebijakan adalah tahap implementasi. Implementasi merupakan kegiatan antara formulasi kebijakan dengan hasil kebijakan yang telah ditentukan. UGM menyusun pedoman pengelolaan tata naskah dinas di lingkungan UGM yang termasuk dalam Peraturan Rektor UGM Nomor 2/P/SK/HT/2015 dan kemudian direvisi dalam Peraturan Rektor UGM Nomor 13 Tahun 2018 tentang Tata Naskah Dinas di Lingkungan UGM. Hal tersebut dilakukan dalam rangka menata kembali tata naskah dinas di lingkungan UGM agar sesuai dengan peraturan yang berlaku. Untuk mengetahui hasil kebijakan tersebut perlu dilihat proses implementasinya.

\section{Implementasi Kebijakan}

Implementasi kebijakan merupakan tahap yang penting dalam proses kebijakan publik. Suatu kebijakan harus diterapkan agar sesuai dengan tujuan yang diinginkan. Menurut Nugroho (2003: 158) implementasi kebijakan adalah cara agar sebuah kebijakan dapat mencapai tujuannya. Selanjutnya, Anderson (2003: 27) menjelaskan imlementasi adalah hal yang dilakukan untuk menerapkan suatu kebijakan yang diadopsi.

Van Meter dan Van Horn dalam Winarno (2017:135) mendefinisikan 
implementasi kebijakan publik sebagai tindakan-tindakan yang dilakukan oleh individu-individu (atau kelompokkelompok) pemerintah maupun swasta yang diarahkan untuk mencapai tujuantujuan yang telah ditetapkan dalam keputusan-keputusan sebelumnya. Tindakan-tindakan ini mencakup usahausaha untuk mengubah keputusankeputusan menjadi tindakan-tindakan operasional dalam kurun waktu tertentu maupun dalam rangka melanjutkan usaha-usaha untuk mencapai perubahan besar dan kecil yang ditetapkan oleh keputusan-keputusan kebijakan.

Adapun menurut Grindle (1980:6) "implementasi bertugas membentuk suatu kaitan yang memudahkan tujuan kebijakan dapat terealisasi sebagai dampak dari kegiatan pemerintah. Kebijakan tersebut diterjemahkan ke dalam program-program yang dapat dilakukan sehingga tujuan kebijakan dapat tercapai."

Terdapat beberapa teori dari beberapa ahli mengenai implementasi kebijakan disampaikan Edward (1980: 10) yang berpandangan bahwa variabel dalam implementasi kebijakan publik yaitu komunikasi (communication), sumber daya (resources), disposisi atau sikap (dispositions or attitudes), dan struktur birokrasi (bureaucratic structure). Selanjutnya, menurut van Meter dan van Horn dalam Winarno (2017: 142-155) ada enam variabel yang membentuk kaitan antara kebijakan dengan kinerja yaitu ukuran-ukuran dasar dan tujuan-tujuan kebijakan, sumber- sumber kebijakan, komunikasi antar organisasi dan kegiatan-kegiatan pelaksanaan, karakteristik badan-badan pelaksana, kondisi-kondisi ekonomi, sosial, dan politik, dan kecenderungan pelaksana (implementor).

Keberhasilan implementasi menurut Grindle (1980: 8-15) dipengaruhi oleh dua variabel besar, yakni isi kebijakan (content of policy) dan lingkungan implementasi (context of implementation). Isi kebijakan terdiri dari segala karakter yang ada dalam kebijakan tersebut, sedangkan lingkungan implementasi terdiri dari segala karakter yang ada di lingkungan proses implementasi berlangsung.

Isi kebijakan mencakup kepentingan yang dipengaruhi: jenis manfaat yang dihasilkan, derajat perubahan yang diinginkan, kedudukan pembuat kebijakan, pelaksana program, dan sumber daya yang dilibatkan. Lingkungan implementasi mencakup kekuasaan, kepentingan dan strategi aktor yang terlibat; karakteristik institusi dan rezim; dan kepatuhan dan daya tanggap.

\section{Tata Naskah Dinas}

Tata naskah dinas merupakan tahap pertama dalam proses penciptaan arsip. Berdasarkan Peraturan Kepala Arsip Nasional ANRI Nomor 2 Tahun 2014 tentang Pedoman Tata Naskah Dinas, definisi tata naskah dinas adalah 
pengaturan tentang jenis, format, penyiapan, pengamanan, pengabsahan, distribusi dan media yang digunakan dalam komunikasi kedinasan. Sedangkan naskah dinas adalah informasi tertulis sebagai alat komunikasi kedinasan yang dibuat oleh pejabat yang berwenang di lingkungan lembaga negara, pemerintahan daerah, perguruan tinggi negeri, BUMN/ BUMD dalam rangka penyelenggaraan tugas pemerintahan dan pembangunan. Peraturan Rektor UGM Nomor 13 Tahun 2018 berisi Naskah Dinas adalah informasi tertulis sebagai alat komunikasi kedinasan yang dibuat dan atau dikeluarkan oleh pejabat yang berwenang di lingkungan UGM.

Dalam Modul Tata Naskah Dinas, tujuan tata naskah dinas adalah sebagai berikut.

1. menciptakan adanya keseragaman baik yang menyangkut teknis maupun prosedural penyelenggaraan tata naskah dinas;

2. mewujudkan keterpaduan tata naskah dinas dengan tata kearsipan yang semakin berdaya guna dan berhasil guna;

3. menunjang kelancaran komunikasi kedinasan dan kemudahan dalam pengendalian pelaksanaannya;

4. meningkatkan hasil guna dan daya guna secara berkelanjutan dalam penyelenggaraan tugas-tugas umum pemerintahan dan pembangunan; dan

5. mencegah dan mengurangi terjadinya kesimpangsiuran, tumpang tindih, salah tafsir dan pemborosan dalam komunikasi kedinasan.

Menurut Muhidin dan Winata (2016: 44), asas penerapan tata naskah dinas terdiri dari asas efisiensi, asas pembakuan, asas pertanggungjawaban, asas keterkaitan, asas kecepatan dan ketepatan, dan asas keamanan.

\section{PEMBAHASAN}

\section{Implementasi Pembuatan Surat Dinas di UGM}

Menurut Muhidin dan Winata (2016: 44), salah satu asas penerapan tata naskah dinas adalah asas pembakuan yaitu, surat dinas atau naskah dinas pada waktu diproses dan disusun menurut tata cara serta bentuk-bentuk yang telah ditetapkan. Dalam petunjuk teknis yang diterbitkan oleh tiap-tiap instansi perlu diadakan pembakuan untuk instansi yang bersangkutan, dengan memperhitungkan kegiatan bersifat khusus yang khas bagi instansi yang bersangkutan agar diperoleh efisiensi dan efektivitas.

Pembakuan naskah dinas yang ada di lingkungan UGM diwujudkan dalam peraturan rektor. Kebijakan UGM terkait dengan tata naskah dinas mengalami perkembangan dan penyesuaian memakan waktu yang cukup lama. Saat in i kebijakan yang mulai diimplementasikan adalah Peraturan Rektor UGM Nomor 13 Tahun 2018 tentang Tata Naskah Dinas di Lingkungan UGM. 
Untuk memperoleh gambaran tentang implementasi tata naskah dinas yang ada di UGM, pembahasan akan difokuskan pada jenis naskah dinas yaitu berupa surat dinas yang meliputi kelengkapan bagian surat, format, penomoran, dan kewenangan penanda tangan naskah dinas. Untuk mengetahui implementasi di unit kerja, analisis dilakukan terhadap contoh beberapa surat dinas yang dibuat pada tahun 2019 . Analisis dilakukan dengan menilai kesesuaian antara surat yang dibuat oleh unit kerja dengan Peraturan Rektor UGM Nomor 13 Tahun 2018.

\section{Kelengkapan Bagian Surat}

Pada Peraturan Rektor Nomor 13 Tahun 2018, bagian surat dinas terdiri dari kepala surat, pembuka, isi surat, dan penutup. Kelengkapan bagian surat menjadi penting karena segala sesuatu yang sudah diatur dalam peraturan harus dilaksanakan sesuai dengan ketentuan yang ada. Hasil penelitian pada kelengkapan surat menunjukkan bahwa naskah dinas yang dibuat fakultas sudah lengkap bagiannya. Hanya saja masih ada dua fakultas yang belum menyertakan Nomor Induk Pegawai (NIP) pejabat penanda tangan surat. Semua bagian surat seperti yang ada dalam peraturan rektor harus dicantumkan dalam pembuatan surat, kecuali ada klausul tidak harus ada seperti lampiran dan tembusan.

Berikut ini kelengkapan bagian surat pada masing-masing fakultas.

Tabel 1

Kelengkapan Bagian Surat

\begin{tabular}{|c|l|c|c|c|c|}
\hline No & \multicolumn{1}{|c|}{ Fakultas } & $\begin{array}{c}\text { Kepala } \\
\text { surat }\end{array}$ & Pembuka & Isi & Penutup \\
\hline 1 & Farmasi & ada & ada & ada & ada \\
\hline 2 & Ilmu Budaya & ada & ada & ada & NIP tidak ada \\
\hline 3 & MIPA & ada & ada & ada & ada \\
\hline 4 & Kehutanan & ada & ada & ada & ada \\
\hline 5 & $\begin{array}{l}\text { Kedokteran } \\
\text { Hewan }\end{array}$ & ada & ada & ada & ada \\
\hline 6 & Kedokteran Gigi & ada & ada & ada & ada \\
\hline 7 & Psikologi & ada & ada & ada & NIP tidak ada \\
\hline 8 & Teknik & ada & ada & ada & ada \\
\hline 9 & $\begin{array}{l}\text { Sekolah } \\
\text { Pascasarjana }\end{array}$ & ada & ada & ada & ada \\
\hline
\end{tabular}

Sumber: analisis peneliti, 2019 


\section{Format naskah dinas}

Format yang akan dibahas adalah kepala surat dinas (kop surat) dan huruf yang digunakan.

\section{Kepala Surat Dinas}

Pengaturan kepala naskah dinas yang benar sesuai peraturan rektor yang berbentuk surat terdiri atas bagian-bagian sebagai berikut.

a. pada kepala naskah dinas universitas dicantumkan lambang universitas, nama universitas, dan alamat dengan warna biru (RGB: 0, 30, 98);

b. lambang universitas dicetak dengan ukuran tinggi $2 \mathrm{~cm}$ dan lebar $2 \mathrm{~cm}$;

c. lambang universitas dicetak dengan batas dari tepi atas kertas $1,5 \mathrm{~cm}$ dan dari tepi kiri kertas $2 \mathrm{~cm}$;

d. nama UGM pada baris pertama dan fakultas/ sekolah serta Unit penunjang pada baris kedua dicetak dengan huruf kapital;

e. nama UGM dicetak tebal apabila tidak diikuti nama fakultas/ sekolah dan unit penunjang;

f. nama fakultas/ sekolah, pusat studi, dan unit penunjang dicetak lebih tebal dari pada nama UGM;

g. alamat ditulis lengkap pada baris akhir tanpa singkatan, disertai kode pos, nomor telepon, faksimile, dan laman apabila ada; dan

h. penulisan nama UGM, fakultas/ sekolah, pusat studi, dan unsur penunjang menggunakan huruf Times New Roman ukuran 16 (enam belas), dan alamat menggunakan huruf Arial ukuran 10 (sepuluh).

Hasil penelitian menunjukkan bahwa hampir semua fakultas menggunakan kepala surat yang belum sesuai dengan ketentuan dalam peraturan rektor. Implementasi format kepala naskah dinas yang sudah mengacu peraturan rektor ada yang sudah sesuai, ada yang belum sesuai, dan ada yang belum mengacu pada peraturan rektor. Biasanya kepala surat dinas ini sudah dalam bentuk cetak.

Kepala surat dinas yang tidak sesuai dengan peraturan rektor secara sekilas tidak ada perbedaan. Hanya saja, apabila lebih diperhatikan dengan seksama terdapat perbedaan yaitu pada ukuran lambang UGM yang lebih besar atau lebih kecil dari ketentuan. Penggunaan huruf pada nama dan alamat unit kerja juga tidak sesuai ukuran dan warnanya. Selain itu, jarak tepi atas dan tepi kiri kertas kurang atau lebih dari ketentuan. 
Tabel 2

Format Kepala Dinas

\begin{tabular}{|c|c|c|c|c|}
\hline No. & Fakultas & $\begin{array}{c}\text { Ukuran } \\
\text { Lambang }\end{array}$ & $\begin{array}{c}\text { Jenis Huruf, } \\
\text { Ukuran dan Warna }\end{array}$ & Batas Tepi \\
\hline 1 & Farmasi & $\begin{array}{l}\text { tinggi: } 1,8 \mathrm{~cm} \\
\text { lebar: } 1,8 \mathrm{~cm}\end{array}$ & $\begin{array}{c}\text { nama: Arial } 14 \\
\text { alamat: Arial } 10 \\
\text { warna: biru }\end{array}$ & $\begin{array}{l}\text { atas: } 2,1 \mathrm{~cm} \\
\text { kiri: } 2,8 \mathrm{~cm}\end{array}$ \\
\hline 2 & Ilmu Budaya & $\begin{array}{l}\text { tinggi: } 2,2 \mathrm{~cm} \\
\text { lebar: } 2,2 \mathrm{~cm}\end{array}$ & $\begin{array}{c}\text { nama: Arial } 16 \\
\text { alamat: Arial } 10 \\
\text { warna: biru }\end{array}$ & $\begin{array}{l}\text { atas: } 1,9 \mathrm{~cm} \\
\text { kiri: } 2,4 \mathrm{~cm}\end{array}$ \\
\hline 3 & MIPA & $\begin{array}{l}\text { tinggi: } 2,4 \mathrm{~cm} \\
\text { lebar: } 2,4 \mathrm{~cm}\end{array}$ & $\begin{array}{c}\text { nama: Arial } 16 \\
\text { alamat: Arial } 10 \\
\text { warna: biru }\end{array}$ & $\begin{array}{l}\text { atas: } 2 \mathrm{~cm} \\
\text { kiri: } 2,2 \mathrm{~cm}\end{array}$ \\
\hline 4 & Kehutanan & $\begin{array}{l}\text { tinggi: } 2 \mathrm{~cm} \\
\text { lebar: } 2 \mathrm{~cm}\end{array}$ & $\begin{array}{c}\text { nama: Arial } 16 \\
\text { alamat: Arial } 10 \\
\text { warna: biru }\end{array}$ & $\begin{array}{l}\text { atas: } 1,9 \mathrm{~cm} \\
\text { kiri: } 2,8 \mathrm{~cm}\end{array}$ \\
\hline 5 & $\begin{array}{l}\text { Kedokteran } \\
\text { Hewan }\end{array}$ & $\begin{array}{l}\text { tinggi: } 2 \mathrm{~cm} \\
\text { lebar: } 2 \mathrm{~cm}\end{array}$ & $\begin{array}{c}\text { nama: Arial } 16 \\
\text { alamat: Arial } 10 \\
\text { warna: biru }\end{array}$ & $\begin{array}{l}\text { atas: } 1,5 \mathrm{~cm} \\
\text { kiri: } 3 \mathrm{~cm}\end{array}$ \\
\hline 6 & Kedokteran Gigi & $\begin{array}{l}\text { tinggi: } 2,2 \mathrm{~cm} \\
\text { lebar: } 2,2 \mathrm{~cm}\end{array}$ & $\begin{array}{c}\text { nama: Arial } 16 \\
\text { alamat: Arial } 9 \\
\text { warna: biru }\end{array}$ & $\begin{array}{l}\text { atas: } 0,9 \mathrm{~cm} \\
\text { kiri: } 2 \mathrm{~cm}\end{array}$ \\
\hline 7 & Psikologi & $\begin{array}{l}\text { tinggi: } 2 \mathrm{~cm} \\
\text { lebar: } 2 \mathrm{~cm}\end{array}$ & $\begin{array}{l}\text { nama: Arial } 14 \\
\text { alamat: Arial } 9\end{array}$ & $\begin{array}{l}\text { atas: } 1,7 \mathrm{~cm} \\
\text { kiri: } 2,2 \mathrm{~cm}\end{array}$ \\
\hline 8 & Teknik & $\begin{array}{l}\text { tinggi: } 1,7 \mathrm{~cm} \\
\text { lebar: } 1,7 \mathrm{~cm}\end{array}$ & $\begin{array}{c}\text { nama: Arial } 16 \\
\text { alamat: Arial } 10 \\
\text { warna: hitam }\end{array}$ & $\begin{array}{l}\text { atas: } 3 \mathrm{~cm} \\
\text { kiri: } 2 \mathrm{~cm}\end{array}$ \\
\hline 9 & $\begin{array}{l}\text { Sekolah } \\
\text { Pascasarjana }\end{array}$ & $\begin{array}{l}\text { tinggi: } 2,7 \mathrm{~cm} \\
\text { lebar: } 2,6 \mathrm{~cm}\end{array}$ & $\begin{array}{c}\text { nama: Arial } 16 \\
\text { alamat: Arial } 10\end{array}$ & $\begin{array}{l}\text { atas: } 1,5 \mathrm{~cm} \\
\text { kiri: } 1,1 \mathrm{~cm}\end{array}$ \\
\hline
\end{tabular}

\section{Huruf yang digunakan}

Ketentuan dalam peraturan rektor, huruf yang digunakan dalam pembuatan surat dinas adalah Times New Roman ukuran 12. Implementasinya, penggunaan huruf dalam pembuatan surat dinas masih berbeda-beda. Ada yang sudah sesuai dengan peraturan rektor, yaitu menggunakan jenis Times New Roman ukuran 12, ada yang menggunakan jenis huruf lain yaitu Arial dan Cambria. 
Tabel 3

Jenis dan Ukuran Huruf

\begin{tabular}{|c|l|c|c|}
\hline No. & \multicolumn{1}{|c|}{ Fakultas } & Jenis huruf & Ukuran \\
\hline 1 & Farmasi & Times New Roman & 12 \\
\hline 2 & Ilmu Budaya & Arial & 11 \\
\hline 3 & MIPA & Times New Roman & 12 \\
\hline 4 & Kehutanan & $\begin{array}{c}\text { Times New Roman, } \\
\text { Arial }\end{array}$ & 12 \\
& & Times New Roman & 12 \\
\hline 5 & Kedokteran Hewan & Times New Roman & 12 \\
\hline 6 & Kedokteran Gigi & Times New Roman & 12 \\
\hline 7 & Psikologi & Cambria & 11 \\
\hline 8 & Teknik & Times New Roman & 12 \\
\hline 9 & Sekolah Pascasarjana & \\
\hline
\end{tabular}

Sumber: analisis penulis, 2019

\section{Penomoran}

Salah satu bagian dalam surat dinas yang digunakan untuk melihat kesesuaian dengan peraturan rektor adalah penomoran surat. Nomor surat dinas terdiri dari nomor urut surat keluar, kode universitas, kode unit kerja, kode penanda tangan surat, kode unit pengolah surat, kode hal surat, dan tahun pembuatan surat.

Banyak fakultas yang masih menggunakan format penomoran yang

Tabel 4

Format Penomoran Surat

\begin{tabular}{|c|l|c|c|}
\hline No. & \multicolumn{1}{|c|}{ Fakultas } & Contoh Penomoran & Keterangan \\
\hline 1 & Farmasi & $19.04 .04 / \mathrm{UN} 1 / \mathrm{FFA} .1 / \mathrm{SETPIM} / \mathrm{PT} / 2019$ & sesuai \\
\hline 2 & Ilmu Budaya & $1915 / \mathrm{UN} 1 / \mathrm{FIB} / \mathrm{TU} / 2019$ & tidak sesuai \\
\hline 3 & MIPA & $4 / \mathrm{J} 01.1 .28 / \mathrm{PP} .03 .15 / 2019$ & tidak sesuai \\
\hline 4 & Kehutanan & 378/PD/2019 & tidak sesuai \\
\hline 5 & Kedokteran Hewan & $234 / \mathrm{UN} 1 / \mathrm{KG}$.1/Set.KG/PJ/2019 & tidak sesuai \\
\hline 6 & Kedokteran Gigi & $2187 / \mathrm{UN} 1 / \mathrm{FPsi} 1.2 / \mathrm{TU} / \mathrm{PK} / 2019$ & sesuai \\
\hline 7 & Psikologi & $117 / \mathrm{H} 1.17 / \mathrm{PS} / 2019$ & tidak sesuai \\
\hline 8 & Teknik & $855 / \mathrm{UN} 1 / \mathrm{SPs} .1 / \mathrm{AKM} / \mathrm{PT} / 2019$ & sesuai \\
\hline 9 & $\begin{array}{l}\text { Sekolah } \\
\text { Pascasarjana }\end{array}$ & & \\
\hline
\end{tabular}

Sumber: analisis penulis, 2019 tidak sesuai dengan peraturan rektor. Ada yang masih menggunakan kode J01 yang sesuai dengan Keputusan Menteri Pendidikan dan Kebudayaan Nomor 091/U/1995, ada yang menggunakan kode $\mathrm{H} 1$ yang sesuai dengan Peraturan Menteri Pendidikan Nasional Republik Indonesia Nomor 42 Tahun 2006, dan ada yang menggunakan format penomoran sendiri. 


\section{Kewenangan Penanda Tangan}

Kewenangan penanda tangan surat penting untuk mengontrol unit kerja dalam pembuatan surat. Kewenangan ini sudah diatur dalam Peraturan Rektor UGM Nomor 2/P/SK/HT/2015. Akan tetapi, dengan adanya perubahan struktur organisasi di UGM mengharuskan adanya revisi terhadap peraturan tersebut. Hasil revisi adalah dengan terbitnya Peraturan Rektor UGM Nomor 13 Tahun 2018 tentang Tata Naskah Dinas di Lingkungan UGM.

Pada peraturan rektor yang baru, kewenangan penanda tangan surat dilengkapi sesuai dengan perubahan struktur organisasi. Kewenangan yang semula belum ada, ditambah dan disesuaikan. Misalnya pada peraturan lama pusat studi, Majelis Wali Amanat (MWA), Senat, Sekretaris Rektor, Sekretaris Direktur, Subdirektorat, Ketua Departemen, dan Kepala Laboratorium belum diatur. Kemudian dalam peraturan rektor yang baru, kewenangan tersebut ditambahkan.

Penanda tangan surat harus sesuai dengan kewenangannya. Apabila tidak sesuai, maka surat dianggap tidak sah. Hasil penelitian menunjukkan bahwa kewenangan penanda tangan surat yang dilakukan di fakultas sudah mengikuti alur kewenangan dalam peraturan rektor.
Analisis Implementasi Pembuatan

\section{Surat Dinas di UGM}

Berdasarkan uraian terkait implementasi pembuatan surat dinas di lingkungan UGM yang dibahas berdasarkan sistem klaster dengan perwakilan beberapa fakultas telah menunjukkan bahwa surat dinas yang dibuat belum sesuai dengan Peraturan Rektor UGM Nomor 13 Tahun 2018.

Dalam hal kelengkapan surat, dari analisis yang telah dilakukan menunjukkan bahwa hampir semua fakultas menggunakan kepala surat yang belum sesuai dengan ketentuan dalam peraturan rektor. Implementasi format kepala surat dinas yang sudah mengacu peraturan rektor ada yang sudah sesuai, ada yang belum sesuai, dan ada yang belum mengacu pada peraturan rektor. Biasanya kepala surat dinas ini sudah dalam bentuk cetak.

Kepala surat dinas yang tidak sesuai dengan peraturan rektor secara sekilas tidak ada perbedaan. Hanya saja, apabila lebih diperhatikan dengan seksama terdapat perbedaan yaitu pada ukuran Lambang UGM yang lebih besar atau lebih kecil dari ketentuan. Penggunaan huruf pada nama dan alamat unit kerja juga tidak sesuai ukuran dan warnanya. Selain itu, jarak tepi atas dan tepi kiri kertas kurang atau lebih dari ketentuan.

Berdasarkan contoh kepala surat dinas di fakultas, diketahui bahwa fakultas belum mengimplementasikan format kepala surat dengan benar yang 
meliputi ukuran lambang, ukuran dan warna huruf, dan jarak tepi kiri dan atas kertas. Warna huruf pada nama dan alamat adalah biru (RGB: 0, 30, 98). Penggunaan warna biru pada huruf di masing-masing fakultas berbeda. Ada yang lebih muda, ada yang lebih tua warnanya. Meskipun demikian, kertas yang sudah dicetak kepala surat tetap digunakan. Dengan adanya kesalahan dalam pencetakan kepala surat tersebut menandakan bahwa perhatian dan pemahaman terhadap isi peraturan rektor belum dilakukan.

Huruf yang digunakan dalam pembuatan surat dinas di beberapa fakultas berbeda-beda. Ada yang memang sudah sesuai dengan peraturan rektor, yaitu menggunakan jenis Times New Roman ukuran 12 (dua belas), ada yang menggunakan jenis huruf selain itu, misalnya Arial dan Cambria. Hal ini sesuai dengan pengamatan pada surat yang dibuat oleh unit kerja. Hasil pengamatan pada surat dan keterangan yang disampaikan oleh informan, penggunaan jenis huruf adalah sesuai dengan kebiasaan yang telah dilakukan selama ini.

Format penomoran surat terdiri dari nomor urut surat keluar, kode universitas, kode unit kerja, kode penanda tangan surat, kode unit pengolah surat, kode hal surat, dan tahun pembuatan surat. Apabila surat yang dibuat menggunakan format penomoran tersebut, berarti unit kerja telah mengimplementasikan penomoran surat yang sesuai dengan peraturan rektor.

Hasil analisis menunjukkan banyak fakultas yang masih menggunakan format penomoran yang tidak sesuai dengan peraturan rektor. Ada yang masih menggunakan kode J01 yang sesuai dengan Keputusan Menteri Pendidikan dan Kebudayaan Nomor 091/U/1995, ada yang menggunakan kode $\mathrm{H} 1$ yang sesuai dengan Peraturan Menteri Pendidikan Nasional Republik Indonesia Nomor 42 Tahun 2006, dan ada yang menggunakan format penomoran sendiri.

Secara keseluruhan, dilihat dari kesesuaian dengan Peraturan Rektor UGM Nomor 13 Tahun 2018 , implementasi tata naskah di UGM menunjukkan bahwa belum ada unit kerja y a n g sepenuh y a d a pat mengimplementasikan peraturan rektor tersebut dengan baik dan memenuhi semua unsur surat dinas. Hal ini ditunjukkan dalam tabel sebagai berikut. 
Tabel 5

Tabel Kesesuaian Implementasi Pembuatan Surat Dinas dengan Peraturan Rektor

\begin{tabular}{|c|c|c|c|c|c|c|}
\hline \multirow[t]{3}{*}{ NO } & \multirow[t]{3}{*}{ Fakultas } & \multicolumn{5}{|c|}{ Unsur-unsur Surat Dinas } \\
\hline & & \multirow[t]{2}{*}{$\begin{array}{c}\text { Kelengkapan } \\
\text { Surat Dinas }\end{array}$} & \multicolumn{2}{|c|}{$\begin{array}{c}\text { Format Surat } \\
\text { Dinas }\end{array}$} & \multirow[t]{2}{*}{ Penomoran } & \multirow{2}{*}{$\begin{array}{c}\text { Kewenangan } \\
\text { Penanda } \\
\text { Tangan }\end{array}$} \\
\hline & & & $\begin{array}{c}\text { Kepala } \\
\text { Surat }\end{array}$ & $\begin{array}{c}\text { Jenis } \\
\text { dan } \\
\text { ukuran } \\
\text { huruf }\end{array}$ & & \\
\hline 1 & Farmasi & lengkap & $\begin{array}{l}\text { tidak } \\
\text { sesuai }\end{array}$ & sesuai & sesuai & sesuai \\
\hline 2 & Ilmu Budaya & NIP tidak ada & $\begin{array}{l}\text { tidak } \\
\text { sesuai }\end{array}$ & $\begin{array}{l}\text { tidak } \\
\text { sesuai }\end{array}$ & tidak sesuai & sesuai \\
\hline 3 & MIPA & lengkap & $\begin{array}{l}\text { tidak } \\
\text { sesuai }\end{array}$ & sesuai & tidak sesuai & sesuai \\
\hline 4 & Kehutanan & lengkap & $\begin{array}{l}\text { tidak } \\
\text { sesuai }\end{array}$ & $\begin{array}{l}\text { tidak } \\
\text { sesuai }\end{array}$ & tidak sesuai & sesuai \\
\hline 5 & $\begin{array}{l}\text { Kedokteran } \\
\text { Hewan }\end{array}$ & lengkap & $\begin{array}{c}\text { tidak } \\
\text { sesuai }\end{array}$ & sesuai & tidak sesuai & sesuai \\
\hline 6 & $\begin{array}{l}\text { Kedokteran } \\
\text { Gigi }\end{array}$ & lengkap & $\begin{array}{c}\text { tidak } \\
\text { sesuai }\end{array}$ & sesuai & sesuai & sesuai \\
\hline 7 & Psikologi & NIP tidak ada & $\begin{array}{l}\text { tidak } \\
\text { sesuai }\end{array}$ & sesuai & sesuai & sesuai \\
\hline 8 & Teknik & lengkap & $\begin{array}{l}\text { tidak } \\
\text { sesuai }\end{array}$ & $\begin{array}{l}\text { tidak } \\
\text { sesuai }\end{array}$ & tidak sesuai & sesuai \\
\hline 9 & $\begin{array}{l}\text { Sekolah } \\
\text { Pascasarjana }\end{array}$ & lengkap & $\begin{array}{l}\text { tidak } \\
\text { sesuai }\end{array}$ & sesuai & sesuai & sesuai \\
\hline
\end{tabular}

Sumber: analisis peneliti, 2019

Penggunaan unsur tata naskah dinas yang terdiri dari kepala naskah dinas, jenis dan ukuran huruf, format penomoran dan kelengkapan isi surat yang masih belum sesuai dengan peraturan rektor, dalam masa peralihan masih diperbolehkan. Namun demikian, upaya untuk mengimplementasikan tata naskah dinas sesuai dengan peraturan rektor harus terus dilakukan. Hal ini agar tujuan implementasi dapat dicapai.

Implementasi tata naskah dinas dalam pembuatan surat dinas yang dilakukan fakultas melalui Peraturan Rektor UGM Nomor 13 Tahun 2018 belum sepenuhnya dilakukan dengan baik. Hal ini dimungkinkan karena pada saat ini masih dalam masa transisi dan terdapat beberapa faktor penghambat implementasi tata naskah dinas. Dalam peraturan disebutkan bahwa masa transisi implementasi adalah 1 (satu) tahun. Jadi, setelah melewati 1 (satu) tahun dari tanggal penetapan, semua unit kerja harus sudah mengimplementasikan peraturan tersebut.

\section{Faktor-Faktor yang Mempengaruhi Implementasi Pembuatan Surat Dinas}

Faktor-faktor yang mempengaruhi implementasi tata naskah dinas dapat 
menjadi beberapa faktor pendukung dan penghambat keberhasilan implementasi kebijakan tata naskah dinas di lingkungan UGM. Dalam penelitian ini dibahas faktor-faktor yang menjadi temuan yang merupakan penghambat dan atau pendukung keberhasilan implementasi tata naskah dinas dalam pembuatan surat dinas di lingkungan UGM melalui Peraturan Rektor UGM Nomor 13 Tahun 2018.

\section{Standarisasi Kode}

Dalam implementasi tata naskah dinas melalui Peraturan Rektor UGM Nomor 13 Tahun 2018, isi kebijakan tata naskah dinas mempengaruhi unit $\mathrm{k}$ e $\mathrm{r} \mathrm{j} \mathrm{a}$ $\mathrm{u} \mathrm{n} \mathrm{t} \mathrm{u} \mathrm{k}$ mengimplementasikannya. Fakultas yang belum mengimplementasikan kebijakan tersebut menyatakan bahwa faktor isi kebijakan tata naskah dinas, terutama bagian penomoran, dianggap terlalu panjang dan terlalu banyak kode sehingga sulit dilakukan.

Berdasarkan temuan tersebut, adanya kesulitan menentukan kode dalam penomoran surat disebabkan oleh terlalu panjangnya standar format penomoran. Penomoran yang terdiri dari banyak kode dapat menimbulkan kebingungan petugas. Selain itu, penggunaan kode klasifikasi arsip yang belum familiar juga menyebabkan kesulitan petugas dalam menentukan kode.

\section{Sosialisasi}

Dalam implementasi kebijakan publik, komunikasi merupakan faktor yang mempengaruhi keberhasilan imlementasi kebijakan tersebut. Komunikasi merupakan sarana untuk menyebarluaskan informasi terkait dengan kebijakan yang akan diimplementasikan.

Implementasi kebijakan tata naskah dinas di lingkungan UGM menitikberatkan pada usaha komunikasi antara tim pengawal peraturan yaitu Hukum dan Organisasi (Hukor) dan Tatas Usaha dan Rumah Tangga (TURT) dengan fakultas. Ada beberapa bentuk kegiatan yang telah dilakukan untuk menyebarluaskan informasi terkait dengan Peraturan Rektor UGM tentang Tata Naskah Dinas. Hukor sebagai pihak yang mengawal penyusunan Peraturan Rektor ini telah melakukan sosialisasi dengan cara mencetak peraturan dalam bentuk buku, kemudian mendistribuskan ke semua unit kerja di lingkungan UGM.

Dengan adanya beberapa bentuk sosialisasi yang telah dilakukan yaitu cetak peraturan, sosialisasi, workshop, uji publik, dan diklat tata naskah dinas, seharusnya implementasi tata naskah dinas di fakultas dapat berjalan dengan lancar. Namun, ternyata implementasi yang dilakukan belum sepenuhnya atau masih setengah-setengah, bahkan belum dilaksanakan. Komunikasi dapat mendukung implementasi 
kebijakan apabila transmisi atas kebijakan dapat dilakukan dengan baik. Selain itu, komunikasi yang dilakukan harus jelas dan konsisten. Hal ini sesuai dengan teori George C. Edward III terkait dengan faktor komunikasi sebagai variabel yang mempengaruhi implementasi kebijakan. Apabila komunikasi yang dilakukan dalam rangka implementasi tata naskah dinas yang sesuai dengan peraturan rektor dapat dilakukan dengan pemahaman yang baik, jelas dan dilakukan secara konsisten oleh semua pihak yang terlibat, maka implementasi tata naskah dinas dapat dilakukan dengan baik.

\section{Kompetensi Pegawai}

Sumber Daya Manusia (SDM) berperan sangat penting dalam implementasi kebijakan. Implementasi tidak akan berjalan efektif apabila sumber daya manusia yang terlibat untuk melaksanakan kebijakan kurang berkompeten, meskipun isi kebijakan telah dikomunikasikan dengan jelas dan konsisten

Pegawai pelaksana teknik pembuatan naskah dinas sangat penting sebagai pelaksana kebijakan tata naskah dinas. Mengingat setiap fakultas mempunyai struktur organisasi yang cukup besar, kebutuhan SDM sebagai pelaksana teknis dalam pembuatan naskah dinas juga banyak. Setiap pegawai yang menangani pembuatan surat harus memahami isi peraturan tata naskah dinas. Kompetensi sebagai pengelola surat juga sangat mendukung keberhasilan implementasi tata naskah dinas.

Faktor kompetensi pegawai ini sesuai dengan teori dari Edward III yang menyatakan bahwa sumber daya yang dapat mendukung implementasi kebijakan dapat efektif dilakukan yaitu berupa staf yang relatif cukup jumlahnya dan mempunyai keahlian dan keterampilan dalam melaksanakan kebijakan. Hal ini menunjukkan bahwa pegawai yang berkompeten akan berdampak baik dalam implementasi kebijakan.

\section{Penggunaan Sistem Informasi}

Fasilitas yang berperan dalam implementasi tata naskah dinas di fakultas adalah adanya sistem informasi. Pada implementasi tata naskah dinas, ada fakultas yang telah menggunakan sistem informasi untuk menunjang kelancaran pemrosesan surat. Namun, ada fakultas yang justru mengalami kendala dalam penomoran surat. Semua bagian surat sudah mengacu pada peraturan rektor, tetapi dengan adanya sistem informasi yang belum disesuaikan, penomoran justru belum menggunakan format penomoran yang benar.

Penggunaan sistem informasi dalam implementasi tata naskah dinas seharusnya disertai dengan penyesuaian setiap unsur naskah dinas 
yang sesuai dengan peraturan rektor. Hal ini dilakukan agar sistem informasi yang digunakan bukan sebagai penghambat, tetapi sebagai pendorong dalam implementasi tata naskah dinas.

\section{Komitmen Pimpinan}

Faktor ini menyoroti pada sikap para implementor berupa komitmen pimpinan dalam implementasi tata naskah dinas. Setelah mengikuti diklat tata naskah dinas, para pimpinan yang berkomitmen kuat segera melakukan evaluasi diri terkait dengan pembuatan surat yang selama ini dilakukan. Komitmen pimpinan sangat berpengaruh terhadap implementasi tata naskah dinas. Komitmen pimpinan dapat berupa edaran atau perintah untuk melakukan implementasi tata naskah dinas dan kemudahan dalam sosialisasi tata naskah dinas di fakultas. Pimpinan yang mempunyai komitmen yang baik akan segera memberikan dukungan terhadap implementasi. Pimpinan yang kurang berkomitmen menyebabkan dukungan terhadap implementasi hampir tidak ada, sehingga secara tidak langsung akan menghambat unit kerja untuk segera mengimplementasikan tata naskah dinas yang sesuai dengan peraturan rektor.

\section{Kebiasaan}

Salah satu faktor yang menjadi penyebab fakultas belum melakukan implementasi pembuatan surat dinas sesuai dengan peraturan rektor adalah kebiasaan yang dilakukan oleh pegawai yang menangani pembuatan surat dinas. Beberapa fakultas masih melakukan kebiasaan yang selama ini dilakukan dalam pembuatan surat dinas, misalnya dalam penggunaan huruf dan sistem penomoran surat.

\section{KESIMPULAN}

Implementasi tata naskah dinas dalam pembuatan surat dinas melalui Peraturan Rektor UGM Nomor 13 Tahun 2018 belum sepenuhnya dilakukan oleh fakultas. Surat dinas yang dibuat oleh fakultas belum semua memenuhi kelengkapan bagian surat. Dalam hal format surat dinas, kepala surat dan huruf yang digunakan belum sesuai dengan ketentuan dalam peraturan rektor. Penomoran surat dinas sebagian sudah sesuai dengan format yang telah ditentukan, sebagian mengacu pada peraturan lain, dan sebagian yang lain menggunakan format sendiri berdasarkan kebiasaan yang dilakukan selama ini. Pada hal kewenangan penanda tangan naskah dinas, semua fakultas telah melaksanakan sesuai dengan ketentuan dalam peraturan.

Faktor-faktor yang mempengaruhi implementasi tata naskah dinas dalam 
pembuatan surat dinas di lingkungan UGM ada 6 (enam) yaitu standarisasi kode, sosialisasi, kompetensi pegawai, penggunaan sistem informasi, komitmen pimpinan, dan kebiasaan.

Agar keberhasilan implementasi tata naskah dinas dapat dicapai, dalam melakukan sosialisasi peraturan rektor, pihak yang terkait sebaiknya menggandeng Arsip UGM yang salah satu tugasnya adalah melakukan pembinaan kearsipan, terutama dalam penggunaan kode klasifikasi arsip. Selain itu, perlu dilakukan pengawasan kearsipan untuk mengawal implementasi tata naskah dinas dan di tingkat fakultas atau unit kerja sebaiknya ada penanggung jawab yang memastikan bahwa dalam pembuatan surat dinas sudah sesuai dengan peraturan rektor.

\section{DAFTAR PUSTAKA}

Anderson, James E. 2003. Public Policy Making an Introduction. Houghton Mifflin Company, New York.

Arsip Nasional Republik Indonesia. 2009. Modul Tata Naskah Dinas. ANRI, Jakarta.

Azmi. 2016. Signifikansi Empat Instrumen Pokok Pengelolaan Arsip Dinamis. Jurnal Kearsipan. Vol. 11/ANRI/12/2016.

Dunn, William N.. 2003. Pengantar Analisis Kebijakan Publik Edisi Kedua. Gadjah Mada University Press, Yogyakarta.

Edwards III, George C. 1980. Implementing Public Policy. D.C.: Congressional Quarterly Inc,
Washington.

Grindle, Merilee S.. 1980. Politics and Policy Implementation in the Third World. Princeton, Princeton University Press, New Jersey.

Hendrawan, Muhammad Rosyidan, dan Ulum, Muchamad Chazienul. 2017. Pengantar Kearsipan: Dari Isu Kebijakan ke Manajemen. UB Press, Malang.

Ibrahim. 2015. Metodologi Penelitian Kualitatif: Panduan Penelitian Beserta Contoh Proposal Kualitatif. CV.Alfabeta, Bandung.

Moelong, Lexy J. 2016. Metode Penelitian Kualitatif Edisi Revisi. Remaja Rosdakarya, Bandung.

Muhidin, Sambas Ali, dan Winata, Hendri. 2016. Manajemen Kearsipan untuk Organisasi Publik, Bisnis, Sosial, Politik, dan Kemasyarakatan. Pustaka Setia, Bandung.

Nogroho D., Riant. Kebijakan Publik Formulasi, Implementasi, dan Analisis. E lex M edia Komputindo, Jakarta.

Utomo, Warsito. 2012. Administrasi Publik Baru Indonesia Perubahan Paradigma dari Administrasi Negara ke Administrasi Publik. Pustaka Pelajar, Yogyakarta.

Winarno, Budi. 2017. Kebijakan Publik Era Globalisasi Teori, Proses, dan Studi Kasus Komparatif. CAPS, Jakarta.

\section{Peraturan:}

ANRI. 2014. Peraturan Kepala Arsip Nasional ANRI Nomor 2 Tahun 2014 tentang Pedoman Tata Naskah Dinas. Jakarta. 
UGM. 2015. Peraturan Rektor UGM Nomor $2 / \mathrm{P} / \mathrm{SK} / \mathrm{HT} / 2015$ tentang Tata Naskah Dinas di Lingkungan $U G M$. Yogyakarta.

UGM. 2018. Peraturan Rektor UGM Nomor 13 Tahun 2018 tentang Tata Naskah Dinas di Lingkungan UGM. Yogyakarta.

\section{Dokumen:}

Surat Edaran Sekretaris Jenderal Kemenristekdikti Nomor 3775/A.A3/SE/2017 tentang Kewenangan Penandatangan Surat Dinas di Lingkungan Kemenristekdikti.

Surat Sekretaris Utama ANRI Nomor BHM.00/1656/2019 tentang Penipuan Mengatasnamakan Pusdiklat Kearsipan ANRI.

Surat Undangan Nomor B DL.00.02/91/VII/2018 tentang Undangan Diklat Pengelolaan Arsip Dinamis 2018.
Internet:

Aco, Hasanudin. 2018. Penipuan dan Pemerasan Menggunakan Surat Perintah Deputi Pencegahan BNN. www.tribunnews.com. Diakses 16 Januari 2019 (10.45).

Fatima. 2018. Diklat Tata Naskah Dinas: Menuju Standardisasi Tata Naskah Dinas di Lingkungan U $\quad$ G $\quad M$

https://sdm.ugm.ac.id/kegiatan/dikla t-tata-naskah-dinas-menujustandardisasi-tata-naskah-dinas-dilingkungan-ugm/. Diakses pada 18 Desember 2018 (10.58).

Firmana, Adhi. 2017. Uji Publik Rancangan Peraturan Rektor UGM tentang Tata Naskah Dinas UGM. hktl.ugm.ac.id. Diakses pada 24 Januari 2019 (21.35). 